\title{
Poverty and Prosperity: Impact on Livelihood Assets of Billion Trees Afforestation Program in Khyber Pakhtunkhwa (KPK), Pakistan
}

\author{
Tariq Rauf ${ }^{1}$, Naveed Khan ${ }^{1}$, Syed Jamal Shah ${ }^{2}$, Muhammad Zada ${ }^{1}{ }^{10}$, Saqib Yaqoob Malik ${ }^{1}$, \\ Cao Yukun ${ }^{1, *}$ and Adnan Sadique ${ }^{3}$ \\ 1 School of Economics \& Management, Northeast Forestry University, Harbin 150040, China; \\ khoogtm@yahoo.com (T.R.); naveed@nefu.edu.cn (N.K.); m.zada1@hotmail.com (M.Z.); \\ malikhashir58@yahoo.com (S.Y.M.) \\ 2 School of Management, Harbin Institute of Technology, Harbin 150001, China; jimmikakakhail@hotmail.com \\ 3 School of Management, University of Malakand, Malakand 23050, Pakistan; sadiqueadnan09@gmail.com \\ * Correspondence: caoyukun@nefu.edu.cn or cyklk@163.com; Tel.: +86-136-0488-1358
}

Received: 30 August 2019; Accepted: 15 October 2019; Published: 17 October 2019

\begin{abstract}
In this study, we assessed the impact of the Billion Trees Afforestation Program (BTAP) on the livelihood of local household in Khyber Pakhtunkhwa Province (KPK). BTAP is the largest ban-logging afforestation program in Pakistan, which aims to conserve natural forests, promoting rural livelihoods and reducing poverty. Primary data from 360 local inhabitants were collected and analyzed using descriptive and econometric methodologies that include ordered logit model and ordinary least squares (OLS) respectively. In specific, a wealth index, household income, and five assets of sustainable livelihood have been considered to measure the impact of BTAP. We found that there is a strong and positive contribution of BTAP to the improvement of a rural community's livelihood. Results showed that BTAP based households earn $4 \%$ more income and possess around $35 \%$ more assets. These findings suggest that BTAP has considerable effect on increase in livelihood assets. This study continues the discussion with several practical implications of this along with recommendations for future research.
\end{abstract}

Keywords: Billion Tree Afforestation Project (BTAP); sustainable livelihood framework; rural livelihood; forest income; Khyber-Pakhtunkhwa (KPK); Pakistan

\section{Introduction}

Pakistan is a highly populated country in Asia with relatively less forest cover about $2.5 \%$ of its total land. Most of the country's forest is degraded, and recent deforestation reports indicate high prevalence of about $1.65 \%$ [1,2], which was previously recorded at $0.6 \%$ during the period of $1981-1990$ and $1.5 \%$ between 1991 and 2010 [2,3]. Deforestation, desertification, and grassland degradation, among other reasons, have produced huge environmental disturbance, such as dust storms, wildlife habitat loss, reduced water resources and increased soil erosion [4,5]. In addition, people's livelihood has also been affected badly, as shown by the prevalence of food insecurity and poverty, and a decrease in employment [2,6,7]. Qamer [2] asserts that every year in Pakistan 39,000 hectares of natural forest are disappearing. Similarly, 33\% of the participants of a field survey conducted by Qamer [8], noted a serious decline in the Khyber Pakhtunkhwa Province (KPK) forest cover from 2000 to 2012.

Khyber Pakhtunkhwa Province (KPK) in Pakistan is one of the provinces that have the widest forest cover (40\%) [4] specifically in the Shangla, Chitral, Dir, Swat and Hazara districts within the $\mathrm{KP}$ province [5]. Along with the high forest cover area, this province is also one of the provinces identified as the highest hotspots for loss of biodiversity in Pakistan [6] and endowed with several 
fragmented and fragile ecosystems, land-use and land-cover changes (LULCC) have faster damaging processes with irreversible effects on ecosystems [7]. The area of forest in this region declined by $30.5 \%$ from 1968-2010 due to the high conversion of forest land to agricultural land [8]. Other studies have found that deforestation is caused by agriculture expansion, population pressure, commodity and timber prices, wage levels, population growth, tourism, improvement of accessibility and increase of linkages between high and low lands, change in lifestyle and cultural patterns, opening to the external economies and global economic integration, external interventions in the form of development initiatives, and lack of governmental policies and high illegal harvesting activities [3,9-12]. However, the natural environment particularly in rural regions of KPK has been affected in recent decades by natural disasters (earthquake 2005, torrential rains of 2010), fluctuating monsoon rains and rising temperature [13].

To overcome these problems in Pakistan, the government has made various efforts in the form of policies and programs including being active members of the Coalition of Rainforest Nations (CRN). Thus, in 2011, Pakistan initiated the reducing emissions from deforestation and forest degradation (UN-REDD) project and is receiving support funds to improve forest monitoring system nationally and REDD readiness roadmap. Further, Pakistan has launched a Mega-Carbon Sequestration project, which aims to fulfill REDD objectives in the longer run [14,15]. As a follow up to the afforestation/reforestation program in Pakistan, the Government of KPK Province launched the Billion Trees Afforestation Program (BTAP), which began in 2014 and extends until 2030 [16,17]. BTAP is the largest Afforestation and reforestation initiatives [12] in Pakistan by planting up to 350,000 Ha [4]. BTAP was implemented in three phases. During Phase 1, the government approved a budget of Rs. 1815.18 million that was the initial phase. Subsequently, Phase 2 was the main implementation and execution phase with total budget of Rs. 8217.25 million. For Phase 3, the government allocated a total budget of Rs. 7710 million to protect and maintain the built assets. According to the local government, BTAP is totally different from the other projects that were launched in Pakistan for a couple of reasons. First, BTAP objectives are not only to protect or restore the degraded forest, but also to improve the local household's livelihoods within different projects activities [18,19]. The inhabitants of far flung rural areas like in this study site have limited opportunities for the generation of income, and limited availability of financial support (bank loans). Most of their income is spent for their daily needs, while savings for contingencies are usually in the form of agricultural products (grains), domestic animals or valuable trees [7]. With the initiative of BTAP, a large increase in the number of small-scale nursery firms has been observed, which is one of the significant forms of BTAP. The KPK government believes that such firms have significantly enhanced livelihood by producing employment and other jobs opportunities $[13,20]$. Moreover, BTAP is a significant source of several kinds of livelihood opportunities that include, increase fuel woods, nurseries, non-timber products (i.e., honey, beeswax, traditional medicines, mushrooms, and edible fruits), ecotourism and other small business, are anticipated to have contributed to the understudied population's livelihood [21]. Additionally, BTAP can offer a significant contribution in the development of rural communities in KPK Pakistan. Khan, Shah [13] found in their study during the field survey that BTAP has rehabilitated the ecosystem and increased the income and livelihood of the local rural areas of KPK. According to an independent monitoring agency, World Wide Fund for Nature (WWF) [19] in July 2017 the average survival rate of the plantation of BTAP was $88.75 \%$.

Like the Forest Landscape Restoration (FLR) approaches discussed in the Bonn Challenge [22], multiple outcomes of BTAP affect each other which aim to protect watersheds, conserve natural forests and develop the well-being of local households [13]. Due to inadequate resources and opportunities, most of the rural communities generate their livelihood from forest-related products and it serves as an anti-catalyst agent in rural people livelihoods [23]. Figure 1 shows the thinking framework of how BTAP can reach its outcome to maintain the function of forest ecosystems, local livelihood, well-being, and resilience (LLWR). This framework has been modified from the FLR mindset. In its implementation, BTAP was able to directly carry out restoration by planting forest land and using local communities 
for the supply of seeds, seedling maintenance, planting to tree maintenance. Through this process, outcomes are generated directly through lines $1 \rightarrow 3$ and $2 \rightarrow 3$. A restoration program is a long-term process and effort [22]. BTAP projects aim to restore natural forest ecosystem and also contribute to LLWR, with their specific methods, objectives, or causal pathways of impacts and influence [24]. Under a first pathway, the BTAP Program is targeted or designed to impact forest outcomes with LLWR outcomes considered as a secondary aim or knock-on effect (Pathway 1-3, Figure 1). Under a second pathway, the BTAP Program is directly designed and predominantly targeted towards LLWR outcomes (Pathway 2, Figure 1), with forest outcomes occurring as a downstream effect (Pathway 2-3, Figure 1).

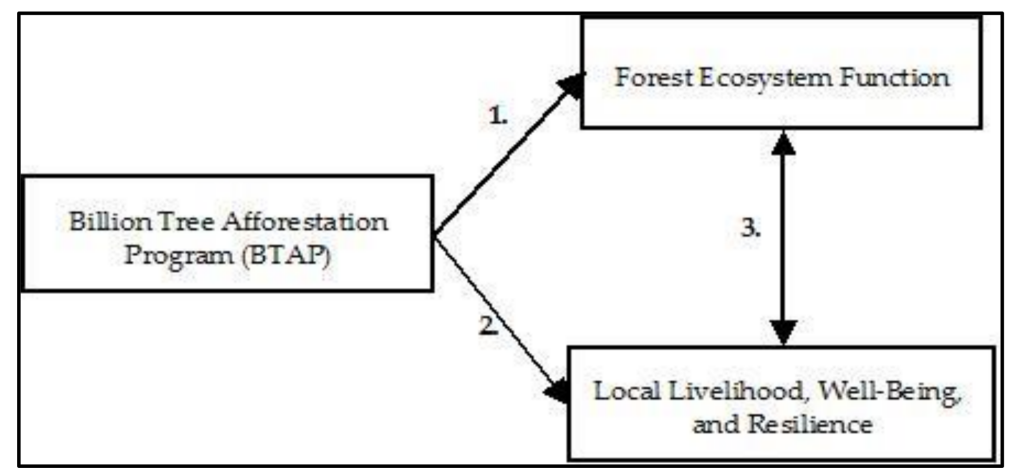

Figure 1. Billion Trees Afforestation Program (BTAP) thinking framework.

Some research has shown the success of the program. According to a study conducted by Munawar, the carbon stock contained in the KPK increased along with various reforestation programs and became a suitable site for the execution of the REDD+ program [15]. These will also support community livelihoods by allowing it to sell carbon credits. This revenue can be utilized to provide a sustainable livelihood to forest dependent households and for forest conservation in Pakistan [1].

So far there have been studies but they have not demonstrated in depth how livelihood can be analyzed comprehensively, transdisciplinary, and deeply. In fact, according to Khan, Shah [13] there is a need for in-depth research and strategies on how the livelihood can be sustainable. Quantifying the indirect and absolute contribution of BTAP income to total income collection is significant for understanding the livelihoods of rural communities, the wellbeing implications of degraded natural assets, the poverty and disparity level, and the design of efficient developmental and conservation strategies [13]. The analysis of sustainable livelihood framework issued by the UK's Department for International Development (DFID) can be the right choice [25]. Scope, objectives, and significances for development is way of thinking about livelihoods approach, which has been extensively applied in ecosystem studies $[1,12,25]$. Though, we have not observed any research that takes into account the effects of BTAP on the development of livelihood of poor rural communities, in Pakistan. Based on these opinions, the current research empirically evaluated the impacts of BTAP on the rural communities' livelihood.

The remaining paper is organized as: Section 2 explains the conceptual framework. Section 3 defines the materials and methods of the study. Section 4 discusses the study results and finally, Section 5, highlights study limitations and provides recommendations for future research with conclusions.

\section{Sustainable Livelihood Conceptual Framework}

The sustainable rural livelihood framework (SLF) is a theoretical framework with a complete holistic and interdisciplinary perspective, by which DFID addresses employees' involvements in beneficiary countries that covers the several dimension of livelihood and the extensive level of socioeconomic and other factors which contribute to it (Adato and Meinzen-Dick, 2002). This framework analyzes livelihood activities, people's access to resources, causes of poverty, and their relationships [26,27]. The focus in SLF is a household's status and to investigate ecological, economic and social factors which influence their potentiality to build sustainable livelihood approaches. 
Furthermore, SLF not only analyses incomes and consumption but also provides a good understanding about poverty and to improve living standard [28]. SLF is based on a largely qualitative approach that identifies the vulnerabilities of different groups to shocks and stresses through an analysis of their capital assets. According to the concept, within the framework of prevailing polices and a range of vulnerabilities and organizations and methods, a household selects different strategies of livelihood based on the assets that have been available, which results in certain livelihood outcomes which then feed back into the assets and improved livelihoods [29-32]. Figure 2 below presents a theoretical model about BTAP SLF and defines a brief description of the livelihood strategies, assets and livelihood outcomes.

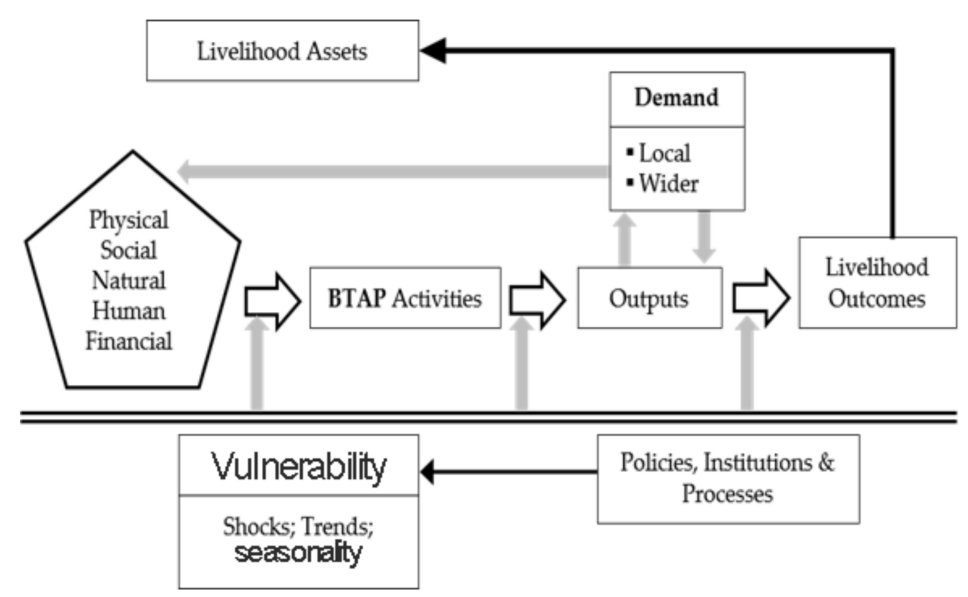

Figure 2. Sustainable rural livelihood framework (SLF) thinking framework on BTAP project.

Most examples of livelihoods-based analysis can be found in developing countries. In the last few decades, the SLF has come under consideration by researchers. According to this framework, an individual's access to capital assets, their capability to generate livelihood strategies by the combination of various capital assets, and the power to enlarge their asset base following the communication with other actors [33-35] constitutes an individual's livelihood. Five types of capital assets are included: human capital, financial capital, physical capital, social capital, and natural capital, and others all basics elements. All of these are deeply interlinked (Pandey, 2005) and are essential for a sustainable rural livelihoods [36-38]. The existing study uses this five-capital assets framework for evaluating the impact of BTAP on the livelihood of a rural community. Many studies have thus investigated whether or not forest resources enhance rural livelihoods [38].

Human capital refers to the knowledge, education, training, and the capability to do work in excellent health that empower individuals to follow livelihood strategies [39-41].

Financial capital defines the economic resources that are obligatory by an individual to meet livelihood goals. These may include employment, savings, income, etc. [36,42,43].

Physical capital comprises basic infrastructures such as transport, market access and goods which are essential for promoting and supporting rural livelihood. [29,44,45].

Social capital represents the features of a social organization that serve to coordinate actions. These are social resources individuals draw on in search of livelihood objectives and include decision-making power, cooperation, and social prestige [46-48].

Natural capital includes the natural reserves that are essential contributions for the poor households and from which livelihood is generally derived. It ranges from both tangibles to intangible goods, such as air quality, soil quality, biodiversity and saline and lodging for a healthy environment $[36,37]$.

To sustain well-being and adaptive capability, a household is expected to need these five capitals in a balanced amount [49]. The creation of livelihood assets may improve the ability of households to give a timely response to shocks. The SLF also provides the variety of assets that households use for 
improving their livelihoods [50] and trying to understand the fluctuating arrangements of events of livelihood in a historical and changing background [51].

The SLF offers an innovative technique for establishing indicators of forest program. As Carney [25] state that, "The capital assets process to measure livelihoods is a suitable organizing standard principle for the selection of indicators' to evaluate the forest impact on rural households' livelihood." It ensures that quite a few indicators are considered, including social, material, and natural components that are likely to assist in examining the effect on the forest.

Finally, BTAP in the shape of privately owned nurseries, enhancing (NTFP) non-timber forest products (Honey bees box) is the major source of sustainable rural household livelihoods [33]. Based on the literatures, we evaluate this assessment with including local, individual ideas of livelihood in indicators. Further, to examine the impact of BTAP on the livelihood of rural household the indicators were translated with quantitative questions to ask local surveyed households. Responses for the five livelihood capitals were aggregated for all and each BTAP household. This process is shown below in Figure 2 and further explained in the data analysis section. The methods used in this paper focus on assessing the impact of BTAP on the rural community livelihood. Using the five capital assets of livelihood enabled us to compare and contrast the livelihood capitals between households and examine the effect of BTAP on rural livelihood. In the current study we used a sustainable livelihoods technique to assess the impacts of BTAP on local rural households' livelihoods because it has been extensively used $[33,34,36,37]$.

\section{Materials and Methods}

\subsection{Study Site}

The current research was conducted in two districts of Khyber Pakhtunkhwa Province (KPK) (see Figure 3), namely: Shangla and lower Dir. Geographically, these districts cover $3168 \mathrm{~km}^{2}$, and the overall estimated cumulative population of the two sample districts is about 2.19 million [52]. Where Shangla has a population of 0.76 million, while lower Dir has 1.44 million in population [53]. According to United Nation Development Program (UNDP) [54,55], area occupied by natural forest in Shangla, and Lower Dir is $49.9 \%$, and $26.7 \%$ respectively. Furthermore, Shangla is less-developed and the most of the poorest district of KPK, with the majority of inhabitants living in remote rural areas. Lower Dir has a combination of rural and urban regions [53,55]. In terms of forest setup, Shangla and Lower Dir, each have 3 forest sub-divisions [8]. The majority of inhabitants of these districts lacks basic facilities required for everyday life. The basic source of their income is small scale farming, livestock, remittances, and other local businesses. Therefore, these factors have made the study area an ideal place to examine the impacts of BTAP on rural livelihoods.

\subsection{Questionnaire Design, Sampling Technique and Data Collection}

The data used in this study were obtained from the household survey based on a systematically formulated strategy [56-59], using a pre-designed questionnaire during 2018. (Questionnaire in Appendix C). To avoid confusion between items or ambiguities in the response categories, the designed questionnaire was pre-tested in the first week of March 2018 on a sample of 60 households in KPK. At the middle of April 2018, an 8-person investigation team surveyed two districts of KPK Province, where the BTAP was implemented. As mentioned above, altogether Shangla and lower Dir comprise 6 forest sub-divisions, of which, we randomly chose 4 sub-divisions of the forest. We chose randomly 2 out of 3 each from Shangla and Lower Dir. In specific terms, we chose sub-divisions of forest from district Shangla were Alpuri, and Karora, while the sub-divisions of Timergrra and Chakdara were nominated from district Lower Dir. Then union councils, villages, and households were randomly selected from each of selected forest sub-divisions. Overall, two union councils (UC) were randomly selected in each forest sub-division $(2 \times 4=8 \mathrm{UC})$, three villages from each union council $(3 \times 8=24$ villages), and around 15 households (treatment and control) randomly selected from every 
village $(15 \times 24=360$ households). The participating and non-participating households (treatment and control) locations were nominated on the basis of being forested districts with socioeconomic outcomes that were as similar as possible. Data from 360 participating and non-participating households revealed that 182 households (102 from Shangla and 80 from Lower Dir) were participated of BTAP, while 178 households (98 from Shangla and 80 from Lower Dir) were not participated in BTAP. As we interviewed, the educational background was mostly low of the households dependent on the forest for their livelihood.

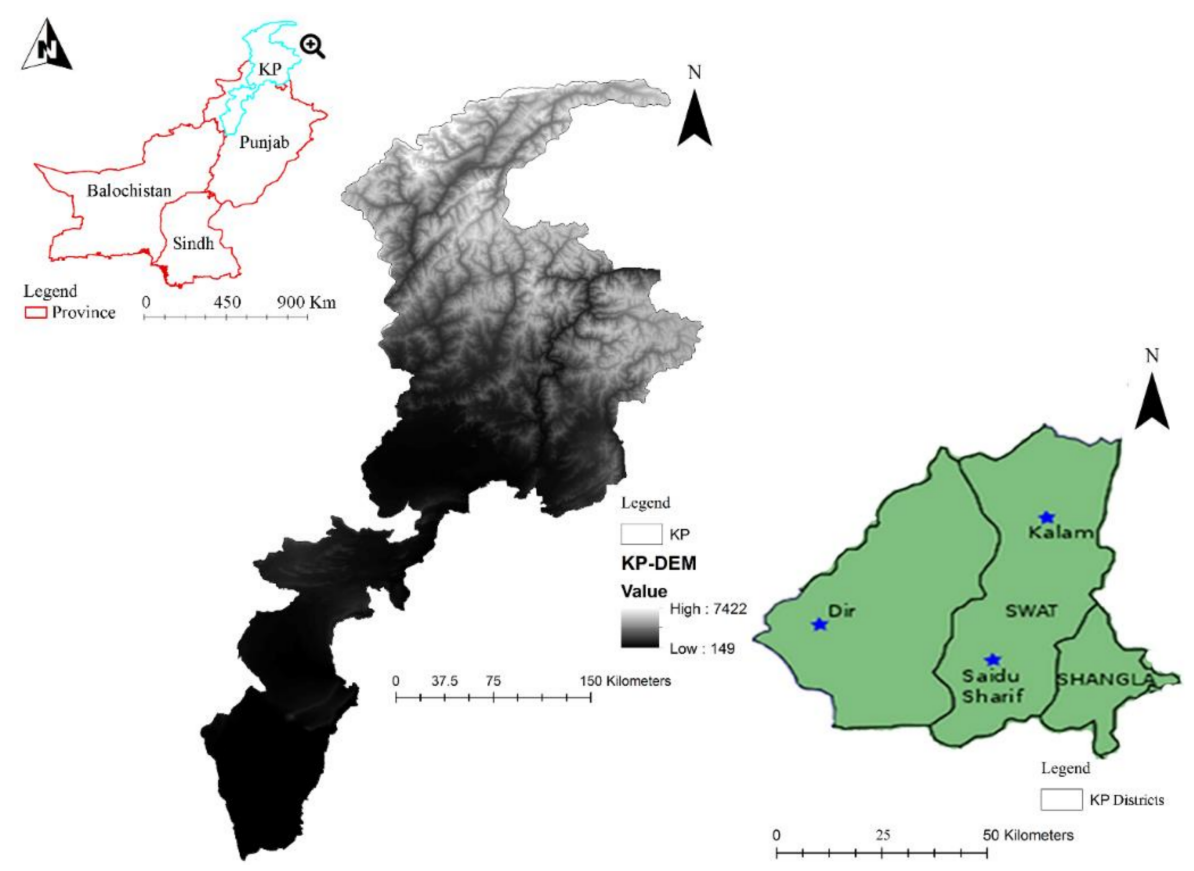

Figure 3. The study area of Khyber Pakhtunkhwa KPK, Pakistan.

\subsection{Strategy for Empirical Results}

For better and meaningful results from the collected data, an empirical strategy was used in this section. Accordingly, this study was aligned as follows: (1) the descriptive results, (2) an estimate of the effects of BTAP on income and wealth possessions of households, and (3) an estimate of the households' perceptions of the BTAP effect on rural livelihood, using ordinal logit regression. The following are these three sections of empirical strategy explained in detail.

\subsubsection{BTAP, Household Income, and Wealth Possessions: The Empirical Model}

This study estimates two equations which evaluate the causal impacts of BTAP on the income and wealth of local households:

$$
\begin{gathered}
\text { Income }_{i}=\alpha_{0}+\alpha_{1} \text { Enterprise }_{i}+\gamma X_{h}+\varepsilon_{i}, \\
\text { Wealth Index }_{i}=\beta_{0}+\beta_{1} \text { Enterprise }_{i}+\gamma Z_{h}+\varepsilon_{i},
\end{gathered}
$$

where Income $_{i}$ and Wealth Index $i$ measure the income level and wealth level for the ith individual, and Enterprise $_{i}$ is a dummy variable that measures whether the given respondent is associated with the BTAP. $X_{h}$ and $Z_{h}$ are household level control variables $\varepsilon_{i}$ is a disturbance term.

To empirically estimate these equations, the widely acknowledged ordinary least squares (OLS) methodology was used, where $\alpha_{1}$ and $\beta_{1}$ stand for the impact of BTAP on household income and wealth.

Methodologically, there are various concerns related to these results. One of the possible concerns is reverse causality. It can be argued that, instead of BTAP impact on wellbeing, it is also highly likely that people with higher levels of income and wealth invest more in BTAP. However, to mitigate 
concerns of reverse causality, research participants were asked a retrospective question about income and wealth for comparison. Interestingly, the results (see Table 1) of that comparison suggest that the probability of reverse causality is negligible.

Table 1. Comparison of participated (treatment group) and non-participated households (control group).

\begin{tabular}{|c|c|c|c|}
\hline \multirow[t]{2}{*}{ Variable } & $\begin{array}{l}\text { Participating Households in Billion } \\
\text { Trees Afforestation Program (BTAP) } \\
\text { (Treatment Group) }\end{array}$ & $\begin{array}{l}\text { Non-Participated Household to } \\
\text { BTAP (Control Group) }\end{array}$ & $\begin{array}{l}\text { Difference } \\
(1-2)\end{array}$ \\
\hline & (1) & (2) & (3) \\
\hline & \multicolumn{3}{|c|}{ Demographic characteristics } \\
\hline Gender $($ Male $=1)$ & 0.89 & 0.87 & 0.02 \\
\hline Age & 37.71 & 37.46 & 0.25 \\
\hline Family Size & 5.52 & 5.44 & 0.08 \\
\hline Employment $(=1)$ & 0.95 & 0.62 & 0.33 \\
\hline Family Income (PKR) & $21,321.21$ & $16,650.7$ & 4670.51 \\
\hline \multirow[t]{2}{*}{ Education } & 1.86 & 1.89 & -0.03 \\
\hline & \multicolumn{3}{|c|}{ Benefit Wealth } \\
\hline Wealth Index (Before BTAP) & 6.5 & & \\
\hline Wealth Index (After BTAP) & 8.6 & 5.9 & 2.7 \\
\hline Number of responses & 182 & 178 & \\
\hline
\end{tabular}

\subsubsection{Billion Trees Afforestation Program (BTAP) and Rural Livelihoods: The Empirical Model}

Besides income and wealth, the effects of the five capitals on BTAP and rural livelihood were studied using the following equations:

$$
\begin{aligned}
& H C_{i}=\theta_{4}+\theta_{5} \text { Enterprise }_{i}+\gamma Z_{h}+\varepsilon_{i}, \\
& F_{i}=\theta_{0}+\theta_{1} \text { Enterprise }_{i}+\gamma Z_{h}+\varepsilon_{i}, \\
& P_{i}=\theta_{2}+\theta_{3} \text { Enterprise }_{i}+\gamma Z_{h}+\varepsilon_{i}, \\
& S C_{i}=\theta_{6}+\theta_{7} \text { Enterprise }_{i}+\gamma Z_{h}+\varepsilon_{i}, \\
& N C_{i}=\theta_{8}+\theta_{9} \text { Enterprise }_{i}+\gamma Z_{h}+\varepsilon_{i},
\end{aligned}
$$

where $H C_{i} F C_{i} P C_{i} S C_{i}$, and $N C_{i}$ respectively measure human, financial, physical, social, and natural capital for the $i$ th individual, and Enterprise $_{i}$ is a dummy variable that measures whether the given respondent is associated with the BTAP. $Z_{h}$ in each equation is the set of household-level control variables. $\varepsilon_{i}$ denotes a disturbance term.

To empirically estimate Equations (3)-(7), ordered logit methodology was used. As mentioned in the questionnaire, the five capitals are measured in 5-scale ordered responses. Technically, OLS methodology cannot provide optimal results when the explanatory variable is ordered responses [60]. In such situations, there is a consensus among the econometricians that the ordered logistic regression model provides efficient results.

\section{Results and Discussion}

\subsection{Descriptive Results}

Table 1 below show the descriptive statistics in two separate columns for the participating households (as the treatment group) and non-participating (as the control group) of BTAP.

In Table 1, the Columns (1) and (2) show the demographic characteristics of treatment and control groups of BTAP. Additionally, it also provides the wealth index for the same groups. The results show that wealth index (out of 11: television, computer, electric fan, tractor, air cooler, car, mobile phone, electric iron, refrigerator, air conditioner, and motorcycle,) of both groups is 8.6 and 5.9, respectively. 
It is evident that there is a substantial difference between the two groups. One question regarding the effects of BTAP on rural livelihood is the possible presence of reverse causality. In order to mitigate the concern of reverse causality, the questionnaire also asks the retrospective question from the respondents to assess their wealth before investment in the BTAP. We found that the wealth of households relying on BTAP was 6.5 before their engagement in BTAP, and the wealth index raised to 8.6 after their engagement in BTAP. These results clearly indicate that BTAP significantly improves the wealth of households.

Table 2 is based on the difference between descriptive statistics of the treatment and control groups. Based on these responses, it can be said that BTAP contributed to all five assets of the SLF. Specifically, regarding human capital, a stable financial position empowered BTAP-reliant on households to deal with issues related to health in a better way and availed to them the best available option in terms of educating their family. In addition, government and non-governmental organizations (NGOs) operating in these areas constantly provided training that significantly improved their business productivity. Further, the positive difference with respect to income, employment, and savings suggest that households participated in BTAP possess high financial capital compared to the non-participating group. Table 2 also suggests that households depend on BTAP are more stable in terms of physical capital, as they possess more assets and access to the products they sell is more convenient compared to the other group. Additionally, the households participated in BTAP had higher social capital compared to their control counterparts, since they were in a position to cooperate with the people around them and thus enjoyed cooperation. In response, people valued their suggestions and respected their decisions. Finally, to some extent, the households participated in BTAP also contributed to natural capital; for example, BTAP enhanced the plant species and biodiversity in the districts, and growth in the number of plantations improved air quality and soil. While these descriptive statistics only provide suggestive evidence, the next section offers empirical evidence based on these statistics.

Table 2. Descriptive statistics of treatment and control group responses.

\begin{tabular}{|c|c|c|c|}
\hline \multirow{2}{*}{ Variable } & $\begin{array}{l}\text { Participated to BTAP } \\
\text { (Treatment Group) }\end{array}$ & $\begin{array}{l}\text { Non-Participated to } \\
\text { BTAP (Control Group) }\end{array}$ & Difference (1-2) \\
\hline & (1) & (2) & (3) \\
\hline & \multicolumn{3}{|c|}{ Human Capital } \\
\hline Health & 4.190 & 2.601 & 1.5891 \\
\hline Education & 4.021 & 2.586 & 1.4352 \\
\hline \multirow[t]{2}{*}{ Training } & 4.215 & 2.813 & 1.4023 \\
\hline & \multicolumn{3}{|c|}{ Financial Capital } \\
\hline Employment & 4.119 & 2.546 & 1.5732 \\
\hline Income & 4.845 & 3.301 & 1.5441 \\
\hline \multirow[t]{2}{*}{ Savings } & 3.915 & 2.603 & 1.3121 \\
\hline & \multicolumn{3}{|c|}{ Physical Capital } \\
\hline Infrastructure & 4.119 & 2.546 & 1.5723 \\
\hline Assets & 3.869 & 2.489 & 1.3808 \\
\hline \multirow[t]{2}{*}{$\begin{array}{l}\text { Market } \\
\text { Access }\end{array}$} & 3.926 & 2.494 & 1.4319 \\
\hline & \multicolumn{3}{|c|}{ Social Capital } \\
\hline $\begin{array}{l}\text { Decision } \\
\text { Making }\end{array}$ & 3.915 & 2.443 & 1.4723 \\
\hline Cooperation & 3.647 & 2.232 & 1.4152 \\
\hline \multirow[t]{2}{*}{ Prestige } & 3.417 & 2.017 & 1.3975 \\
\hline & \multicolumn{3}{|c|}{ Natural Capital } \\
\hline Air & 3.926 & 2.987 & 0.939 \\
\hline Soil & 3.842 & 2.511 & 1.3310 \\
\hline Biodiversity & 4.962 & 3.446 & 1.5162 \\
\hline Saline & 3.942 & 2.536 & 1.4061 \\
\hline Observations & 182 & 178 & \\
\hline
\end{tabular}




\subsection{Results of Ordinary Least Squares (OLS) Regression}

The previous section provides suggestive evidence of BTAP impacts on rural community livelihoods and poverty alleviation. To better understand this relationship, a rigorous empirical strategy is required. This section provides the empirical results of BTAP impact on the differences in observed outcomes (i.e., income and wealth) between the treatment and control groups. In order to do so, Equations (1) and (2) are estimated with OLS, and the results are presented in Table 3. Column (1) of Table 3 shows the results for income differences. It is evident that participated households of BTAP on average earn $4 \%$ more points. This result verifies the suggestive evidence provided in the previous section. Similarly, Column (2) of the table shows that participated households of BTAP own 3.5\% more assets (out of the 11 included in the wealth index), i.e., 35\%, compared to their counterparts. Moreover, $R^{2}$ of income and wealth are 0.71 and 0.76 , respectively, implying that BTAP contribute $71 \%$ variance in predicting income while $76 \%$ in predicting wealth.

Table 3. BTAP and observed outcomes.

\begin{tabular}{ccc}
\hline \multirow{2}{*}{ Independent Variable(s) } & $\mathbf{( 1 )}$ & $\mathbf{( 2 )}$ \\
\cline { 2 - 3 } & Log (Income) & Wealth Index \\
\hline Enterprise $(=1)$ & $0.398^{* * *}$ & $3.530^{* * *}$ \\
& $(0.0151)$ & $(0.0861)$ \\
\hline Gender & -0.0127 & 0.167 \\
& $(0.0167)$ & $(0.151)$ \\
\hline Age & -0.00321 & -0.0275 \\
& $(0.00341)$ & $(0.0257)$ \\
\hline Family Size & 0.00107 & $-0.0646^{*}$ \\
& $(0.00520)$ & $(0.0382)$ \\
\hline Education & 0.00210 & 0.00104 \\
& $(0.00772)$ & $(0.0586)$ \\
\hline Awareness (forestry) & -0.00174 & 0.0204 \\
& $(0.00386)$ & $(0.0289)$ \\
\hline Constant & $9.755^{* * *}$ & $5.823 * * *$ \\
& $(0.0924)$ & $(0.682)$ \\
\hline Observations & 360 & 360 \\
\hline$R$-squared & 0.712 & 0.768 \\
\hline
\end{tabular}

Note: ${ }^{* * *} p<0.01,{ }^{* *} p<0.05,{ }^{*} p<0.1$ with robust standard errors in parentheses.

\subsection{Results of the Ordered Logistic Regression Model}

Similarly, the logit regression model was used to estimate Equations (2)-(7). The results in Table 4 are based on the perceptions of households related to the relative effectiveness of BTAP on rural livelihoods. All columns in Table 4 show the significant effects of BTAP on various dimensions of livelihoods. $R^{2}$ values in Table 4 further specify that BTAP contribute $66 \%$ variance to human capital, $65 \%$ to financial capital, $63 \%$ to physical capital, $61 \%$ to social capital and $59 \%$ to the natural capital of household linked to BTAP. Column 2 indicates that those who are connected to BTAP perceive a higher effectiveness of financial capital than their counterparts. Likewise, Columns 1 and 3-5 show a higher human, physical, social capital, and natural capital respectively, among the households who are related to forest-related services in BTAP. It is worth mentioning that all these regressions include various demographic characteristics of individuals as control variables. Broadly, these results are similar with the literature on forest resources. Particularly, these findings are in line with those of [61,62], where significant effects of forest resources on the individuals livelihood were found. However, previous studies have only focused on income-related benefits of forest resources, whereas this paper also addresses the effects of BTAP on the wealth of households

We further analyzed three specific aspects of the five livelihood measures. Table 5 is based on the effects of BTAP on health, education and training of human capital. Column 1 refers to findings related 
to health. Although the effect of BTAP on health is significant, it is not sizable. Similarly, Column 3 also shows significant but minimal effects of connectedness to forest-related occupations. Conversely, the impact on education in Column 2 is sizable. The significance results of these relationships indicates that local households associated to BTAP can easily manage their health-related difficulties and educate their children and also have many opportunities to train themselves so as to improve their professional performance and potentially their personal life. Broadly, this result is connected with results of Khan, Shah [13], who examined the impacts of BTAP on the livelihoods of rural households.

Table 4. BTAP and rural livelihoods.

\begin{tabular}{cccccc}
\hline \multirow{2}{*}{$\begin{array}{c}\text { Dependent } \\
\text { Variable(s) }\end{array}$} & $\mathbf{( 1 )}$ & $\mathbf{( 2 )}$ & $\mathbf{( 3 )}$ & $\mathbf{( 4 )}$ & $\mathbf{( 5 )}$ \\
\cline { 2 - 6 } & Human Capital & Financial Capital & Physical Capital & Social Capital & Natural Capital \\
\hline Enterprise $(=1)$ & $1.474^{* * *}$ & $1.450^{* * *}$ & $1.487^{* * *}$ & $1.472^{* * *}$ & $1.302^{* * *}$ \\
& $(0.0565)$ & $(0.0579)$ & $(0.0643)$ & $(0.0647)$ & $(0.0541)$ \\
\hline Gender & -0.0701 & 0.0242 & 0.0534 & 0.0214 & 0.0521 \\
& $(0.0895)$ & $(0.0881)$ & $(0.102)$ & $(0.0871)$ & $(0.0942)$ \\
\hline Age & $-1.56 \times 10^{-5}$ & -0.0127 & 0.00789 & -0.006900 & -0.00589 \\
& $(0.0104)$ & $(0.0115)$ & $(0.0121)$ & $(0.0116)$ & $(0.0101)$ \\
\hline Family Size & 0.0226 & -0.00636 & -0.0115 & -0.0301 & 0.000585 \\
& $(0.0266)$ & $(0.0230)$ & $(0.0284)$ & $(0.0285)$ & $(0.0252)$ \\
\hline Education & -0.0399 & 0.0241 & 0.0350 & -0.0434 & $-0.0726^{* *}$ \\
& $(0.0349)$ & $(0.0372)$ & $(0.0398)$ & $(0.0377)$ & $(0.0267)$ \\
\hline Knowledge (forestry) & -0.00251 & 0.0269 & -0.0209 & 0.0237 & -0.00462 \\
& $(0.0272)$ & $(0.0213)$ & $(0.0238)$ & $(0.0252)$ & $(0.0178)$ \\
\hline Constant & $2.498^{* * *}$ & $2.864^{* * *}$ & $2.322 * * *$ & $2.982^{* * *}$ & $2.802^{* * *}$ \\
& $(0.486)$ & $(0.451)$ & $(0.512)$ & $(0.506)$ & $(0.411)$ \\
\hline Observations & 360 & 360 & 360 & 360 & 360 \\
\hline R-squared & 0.663 & 0.652 & 0.632 & 0.613 & 0.591 \\
\hline
\end{tabular}

Table 5. BTAP and human capital.

\begin{tabular}{cccc}
\hline \multirow{2}{*}{ Dependent Variable(s) } & $\mathbf{( 1 )}$ & $\mathbf{( 2 )}$ & $\mathbf{( 3 )}$ \\
\cline { 2 - 4 } & Health & Education & Training \\
\hline Enterprise (=1) & $2.532^{* * *}$ & $2.546^{* * *}$ & $2.723^{* * *}$ \\
& $(0.231)$ & $(0.242)$ & $(0.240)$ \\
\hline Gender & -0.0842 & -0.00801 & -0.321 \\
& $(0.269$ & $(0.275)$ & $(0.315)$ \\
\hline Age & -0.0702 & 0.00522 & $0.0698^{*}$ \\
& $(0.0540))$ & $(0.0358)$ & $(0.0502)$ \\
\hline Family Size & -0.0187 & 0.0626 & 0.121 \\
& $(0.100)$ & $(0.0870)$ & $(0.0728)$ \\
\hline Education & -0.106 & -0.132 & -0.0201 \\
& $(0.144)$ & $(0.121)$ & $(0.143)$ \\
\hline Knowledge (forestry) & $0.143^{*}$ & -0.0898 & -0.00812 \\
& $(0.0889)$ & $(0.0856)$ & $(0.0674)$ \\
\hline /cut1 & $-3.912 * *$ & -1.263 & 1.743 \\
& $(1.631)$ & $(1.834)$ & $(1.757)$ \\
\hline /cut2 & -2.582 & -0.320 & $3.123 *$ \\
& $(1.624)$ & $(1.561)$ & $(1.644)$ \\
\hline /cut3 & -0.572 & 1.252 & $4.693^{* * *}$ \\
& $(1.623)$ & $(1.643)$ & $(1.730)$ \\
\hline /cut4 & 1.201 & $3.056^{*}$ & $6.764^{* * *}$ \\
& $(1.604)$ & $(1.825)$ & $(1.648)$ \\
\hline Observations & 350 & 350 & 350 \\
\hline
\end{tabular}

Note: ${ }^{* * *} p<0.01,{ }^{* *} p<0.05,{ }^{*} p<0.1$ with Robust standard errors in parentheses. 
Table 6 indicates the perceived effects on employment, income, and savings due to a connection with BTAP. Since the dependent variable is an ordinal variable, ordered logit regressions were used for the analysis. Columns 1-3 evidently show that BTAP positively affects employment, income, and savings. These results are same with the findings of Khan, Shah [13] and Ali [9], who found a positive association between forest income and the saving behavior of households.

Table 6. BTAP and financial capital.

\begin{tabular}{|c|c|c|c|}
\hline \multirow{2}{*}{ Dependent Variable(s) } & (1) & (2) & (3) \\
\hline & Employment & Income & Savings \\
\hline Enterprise $(=1)$ & $\begin{array}{c}2.562^{* * * *} \\
(0.213)\end{array}$ & $\begin{array}{c}2.313^{* * *} \\
(0.211)\end{array}$ & $\begin{array}{c}2.341^{* * *} \\
(0.220)\end{array}$ \\
\hline Gender & $\begin{array}{l}-0.230 \\
(0.335)\end{array}$ & $\begin{array}{l}0.0262 \\
(0.342)\end{array}$ & $\begin{array}{c}0.315 \\
(0.312)\end{array}$ \\
\hline Age & $\begin{array}{c}-0.113 * * \\
(0.0395)\end{array}$ & $\begin{array}{l}-0.0262 \\
(0.0386)\end{array}$ & $\begin{array}{c}0.0351 \\
(0.0378)\end{array}$ \\
\hline Family Size & $\begin{array}{l}-0.0741 \\
(0.0845)\end{array}$ & $\begin{array}{c}-0.00498 \\
(0.0865)\end{array}$ & $\begin{array}{l}0.00714 \\
(0.0850)\end{array}$ \\
\hline Education & $\begin{array}{l}0.0205 \\
(0.123)\end{array}$ & $\begin{array}{l}0.0861 \\
(0.135)\end{array}$ & $\begin{array}{l}0.0564 \\
(0.113)\end{array}$ \\
\hline Knowledge (forestry) & $\begin{array}{c}0.0892 \\
(0.0670)\end{array}$ & $\begin{array}{c}0.0782 \\
(0.0696)\end{array}$ & $\begin{array}{l}-0.0276 \\
(0.0654)\end{array}$ \\
\hline /cut1 & $\begin{array}{c}-5.175^{* * *} \\
(1.821)\end{array}$ & $\begin{array}{c}-1.552 \\
(1.537)\end{array}$ & $\begin{array}{c}0.260 \\
(1.503)\end{array}$ \\
\hline /cut2 & $\begin{array}{c}-3.158^{* *} \\
(1.607)\end{array}$ & $\begin{array}{l}-0.809 \\
(1.525)\end{array}$ & $\begin{array}{c}1.401 \\
(1.503)\end{array}$ \\
\hline /cut3 & $\begin{array}{l}-2.502 \\
(1.706)\end{array}$ & $\begin{array}{c}0.769 \\
(1.532)\end{array}$ & $\begin{array}{l}3.203 * \\
(1.513)\end{array}$ \\
\hline /cut4 & $\begin{array}{l}-0.678 \\
(1.659)\end{array}$ & $\begin{array}{c}2.701 \\
(1.642)\end{array}$ & $\begin{array}{c}4.635^{* * *} \\
(1.540)\end{array}$ \\
\hline Observations & 350 & 350 & 350 \\
\hline
\end{tabular}

Note: ${ }^{* *} p<0.01,{ }^{* *} p<0.05,{ }^{*} p<0.1$ with robust standard errors in parentheses.

In connection to this, Table 7 provides estimates of perceived physical capital due to involvement in BTAP forest-related businesses. We found a positive relationship between BTAP and physical asset holdings. Interestingly, the results showed that connecting to BTAP helps households to improve infrastructure, accumulate assets, and increase their market accessibility, which helps them manage their professional and household life properly.

The social capital of households is explored in Table 8. The results recommend that households linked to BTAP have more social capital. Of the different dimensions of social capital outperforms decision-making, cooperation, and social prestige, but the coefficient of all three dimensions indicates a significant effect. It can be said that BTAP-linked individuals help the people of their society in hard times because of their stable financial position. As a result, communities value their suggestions, cooperate with them, and respect their decisions.

The impact of BTAP on natural capital is indicated in Table 9. Specifically, findings indicate that BTAP improves air quality, controls soil erosion, and protects biodiversity, saline and lodging. Results suggest that BTAP impact on natural capital are strong, and was also significant. This indicates that an increase in BTAP has an optimistic effect on the improvement of biodiversity and an increase in plant species. Moreover, a huge number of plantations increases the air and soil quality and enhanced the biodiversity of the districts. 
Table 7. BTAP and physical capital.

\begin{tabular}{|c|c|c|c|}
\hline \multirow{2}{*}{ Dependent Variable(s) } & (1) & (2) & (3) \\
\hline & Road Infrastructure & Physical Assets & Market Access \\
\hline Enterprise $(=1)$ & $\begin{array}{c}2.632 * * * \\
(0.234)\end{array}$ & $\begin{array}{c}2.431^{* * * *} \\
(0.232)\end{array}$ & $\begin{array}{c}2.653^{* * * *} \\
(0.235)\end{array}$ \\
\hline Gender & $\begin{array}{c}0.471 \\
(0.432\end{array}$ & $\begin{array}{l}-0.481 \\
(0.521)\end{array}$ & $\begin{array}{c}0.321 \\
(0.308)\end{array}$ \\
\hline Age & $\begin{array}{c}-0.00673 \\
(0.0458))\end{array}$ & $\begin{array}{c}0.0401 \\
(0.0360)\end{array}$ & $\begin{array}{c}0.0245 \\
(0.0308)\end{array}$ \\
\hline Family Size & $\begin{array}{c}-0.121 \\
(0.0824)\end{array}$ & $\begin{array}{c}-0.0167 \\
(0.100)\end{array}$ & $\begin{array}{c}0.0247 \\
(0.0855)\end{array}$ \\
\hline Education & $\begin{array}{l}0.248^{*} \\
(0.135)\end{array}$ & $\begin{array}{c}-0.0792 \\
(0.203)\end{array}$ & $\begin{array}{l}0.0622 \\
(0.148)\end{array}$ \\
\hline Knowledge (forestry) & $\begin{array}{c}0.0465 \\
(0.0647)\end{array}$ & $\begin{array}{c}0.154 * \\
(0.0831)\end{array}$ & $\begin{array}{c}0.0575 \\
(0.0863)\end{array}$ \\
\hline /cut1 & $\begin{array}{l}-1.173 \\
(1.624)\end{array}$ & $\begin{array}{l}-1.375 \\
(1.538)\end{array}$ & $\begin{array}{l}0.0825 \\
(1.547)\end{array}$ \\
\hline /cut2 & $\begin{array}{c}-0.00760 \\
(1.614)\end{array}$ & $\begin{array}{l}-0.347 \\
(1.734)\end{array}$ & $\begin{array}{c}1.252 \\
(1.675)\end{array}$ \\
\hline /cut3 & $\begin{array}{c}1.659 \\
(1.545)\end{array}$ & $\begin{array}{c}1.423 \\
(1.621)\end{array}$ & $\begin{array}{l}2.754^{*} \\
(1.752)\end{array}$ \\
\hline /cut4 & $\begin{array}{c}3.442 * * \\
(1.764)\end{array}$ & $\begin{array}{c}3.364^{* *} \\
(1.742)\end{array}$ & $\begin{array}{c}4.659 * * * \\
(1.547)\end{array}$ \\
\hline Observations & 350 & 350 & 350 \\
\hline
\end{tabular}

Note: ${ }^{* * *} p<0.01,{ }^{* *} p<0.05,{ }^{*} p<0.1$ with robust standard errors in parentheses.

Table 8. BTAP and social capital.

\begin{tabular}{|c|c|c|c|}
\hline \multirow{2}{*}{ Dependent Variable(s) } & (1) & (2) & (3) \\
\hline & Decision Making & Cooperation & Social Prestige \\
\hline Enterprise $(=1)$ & $\begin{array}{c}2.371^{* * *} \\
(0.179)\end{array}$ & $\begin{array}{c}2.401 * * * \\
(0.232)\end{array}$ & $\begin{array}{c}2.346^{* * *} \\
(0.231)\end{array}$ \\
\hline Gender & $\begin{array}{c}0.178 \\
(0.403)\end{array}$ & $\begin{array}{c}0.00863 \\
(0.469)\end{array}$ & $\begin{array}{l}0.0121 \\
(0.340)\end{array}$ \\
\hline Age & $\begin{array}{c}0.0523 \\
(0.0453)\end{array}$ & $\begin{array}{l}-0.0402 \\
(0.0356)\end{array}$ & $\begin{array}{l}-0.0581 \\
(0.0357)\end{array}$ \\
\hline Family Size & $\begin{array}{c}-0.136 \\
(0.0896)\end{array}$ & $\begin{array}{c}-0.164 \\
(0.0867)\end{array}$ & $\begin{array}{c}0.0581 \\
(0.0862)\end{array}$ \\
\hline Education & $\begin{array}{c}-0.257^{* *} \\
(0.141)\end{array}$ & $\begin{array}{c}-0.0546 \\
(0.126)\end{array}$ & $\begin{array}{l}0.0402 \\
(0.135)\end{array}$ \\
\hline Knowledge (forestry) & $\begin{array}{l}0.164^{* *} \\
(0.0787)\end{array}$ & $\begin{array}{c}0.123 \\
(0.0839)\end{array}$ & $\begin{array}{l}-0.142 * \\
(0.0870)\end{array}$ \\
\hline /cut1 & $\begin{array}{c}-0.0520 \\
(1.873)\end{array}$ & $\begin{array}{c}-3.076^{*} \\
(1.874)\end{array}$ & $\begin{array}{l}-3.675^{*} \\
(1.642)\end{array}$ \\
\hline /cut2 & $\begin{array}{c}1.024 \\
(1.706)\end{array}$ & $\begin{array}{l}-2.014 \\
(1.786)\end{array}$ & $\begin{array}{l}-2.643 \\
(1.765)\end{array}$ \\
\hline /cut3 & $\begin{array}{c}2.552 \\
(1.704)\end{array}$ & $\begin{array}{c}-0.0622 \\
(1.679)\end{array}$ & $\begin{array}{l}-0.875 \\
(1.865)\end{array}$ \\
\hline /cut4 & $\begin{array}{l}4.548^{* *} \\
(1.607)\end{array}$ & $\begin{array}{l}1.750 \\
(1.664)\end{array}$ & $\begin{array}{c}0.854 \\
(1.745)\end{array}$ \\
\hline Observations & 350 & 350 & 350 \\
\hline
\end{tabular}

Note: ${ }^{* * *} p<0.01,{ }^{* *} p<0.05,{ }^{*} p<0.1$ with robust standard errors in parentheses. 
Table 9. BTAP and natural capital.

\begin{tabular}{|c|c|c|c|c|}
\hline \multirow{2}{*}{ Dependent Variable(s) } & (1) & (2) & (3) & (4) \\
\hline & Air Quality & Soil Quality & Biodiversity & Saline and Lodging \\
\hline Enterprise $(=1)$ & $\begin{array}{c}2.602 \text { *** } \\
(0.322)\end{array}$ & $\begin{array}{c}2.0407^{* * *} \\
(0.305)\end{array}$ & $\begin{array}{c}2.748^{* * *} \\
(0.401)\end{array}$ & $\begin{array}{c}2.921^{* * *} \\
(0.264)\end{array}$ \\
\hline Gender & $\begin{array}{c}0.218 \\
(0.341)\end{array}$ & $\begin{array}{c}0.234 \\
(0.368)\end{array}$ & $\begin{array}{c}-0.342 \\
(0.268)\end{array}$ & $\begin{array}{c}0.332 \\
(0.334)\end{array}$ \\
\hline Age & $\begin{array}{c}0.0708 \\
(0.0389)\end{array}$ & $\begin{array}{l}-0.0412 \\
(0.0327)\end{array}$ & $\begin{array}{c}0.0258 \\
(0.0313)\end{array}$ & $\begin{array}{c}0.0524 \\
(0.0433)\end{array}$ \\
\hline Family Size & $\begin{array}{l}* 0.0680 \\
(0.0853)\end{array}$ & $\begin{array}{c}-0.0727 \\
(0.0811)\end{array}$ & $\begin{array}{c}-0.00784 \\
(0.0740)\end{array}$ & $\begin{array}{l}-0.0372 \\
(0.0639)\end{array}$ \\
\hline Education & $\begin{array}{l}-0.403 \\
(0.132)\end{array}$ & $\begin{array}{c}-0.0147 \\
(0.131)\end{array}$ & $\begin{array}{c}-0.232 \text { ** } \\
(0.127)\end{array}$ & $\begin{array}{l}0.0978 \\
(0.129\end{array}$ \\
\hline Knowledge(forestry) & $\begin{array}{c}0.173^{* *} \\
(0.0762)\end{array}$ & $\begin{array}{c}0.117 \\
(0.0569)\end{array}$ & $\begin{array}{l}-0.0139 \\
(0.0725)\end{array}$ & $\begin{array}{c}0.0121 \\
(0.0654)\end{array}$ \\
\hline /cut1 & $\begin{array}{c}-1.0346 \\
(1.794)\end{array}$ & $\begin{array}{c}-3.708 * \\
(1.554)\end{array}$ & $\begin{array}{l}-1.842 \\
(1.817)\end{array}$ & $\begin{array}{l}-2.756 \\
(1.857)\end{array}$ \\
\hline /cut2 & $\begin{array}{c}0.424 \\
(1.632)\end{array}$ & $\begin{array}{l}-1.046 \\
(1.743)\end{array}$ & $\begin{array}{c}-0.0756 \\
(1.742)\end{array}$ & $\begin{array}{l}-1.206 \\
(1.748)\end{array}$ \\
\hline /cut3 & $\begin{array}{c}1.685 \\
(1.562)\end{array}$ & $\begin{array}{c}0.245 \\
(1.561)\end{array}$ & $\begin{array}{c}1.385 \\
(1.615)\end{array}$ & $\begin{array}{c}0.121 \\
(1.547)\end{array}$ \\
\hline /cut4 & $\begin{array}{l}-1.456 \\
(1.835)\end{array}$ & $\begin{array}{c}-2.708 * \\
(1.621)\end{array}$ & $\begin{array}{l}-1.844 \\
(1.914)\end{array}$ & $\begin{array}{l}-2.644 \\
(1.855)\end{array}$ \\
\hline Observations & 350 & 350 & 350 & 350 \\
\hline
\end{tabular}

Note: ${ }^{* * *} p<0.01, * * p<0.05, * p<0.1$ with robust standard errors in parentheses.

This section discusses the empirical results of the effects of BTAP on rural community livelihoods and poverty alleviation in KPK, Pakistan. Using varied econometric techniques, we found positive causal effects of BTAP on livelihood and poverty in households associated with them. More specifically, the results suggest that households linked to BTAP earn more income than other households, own more resources, and report higher ratings regarding various dimensions of livelihood. These results hold for the various aspects of livelihood and are robust in using the different econometric specifications.

\section{Conclusions and Policy Implications}

There is lack of numerical evidence for the role of forest resources in rural livelihood, income and poverty reduction in Pakistan. Using a micro-econometric approach with household primary survey data from districts Shangla and Lower Dir of Khyber-Pakhtunkhwa, Pakistan, the current study has attempted to assess the influence of BTAP on household livelihoods and poverty reduction. Notably, this study makes a significant contribution to the present literature on forestry economics by evaluating the impacts of BTAP on rural poverty reduction and improve rural livelihood.

The main findings of the study are these. First, BTAP was positively linked with rural livelihood in two districts of Khyber-Pakhtunkhwa, Pakistan. Second, by applying the five livelihood capital assets from the SLF as a method for organizing indicators, this study found that households that participated in BTAP earn higher incomes and possess more assets than households that those thast did not participate in BTAP. Our findings are accord to those in previous research of china which suggest that afforestation/reforestation programs are associate with local livelihood and poverty reduction [59,61]. Similarly, people connected with BTAP reported a higher rating of enterprises for their livelihoods. The results are significant for several extents of sustainable livelihood and indicate significant impacts 
of BTAP on human, financial, physical, social, and natural capital. Quantitatively, the effect of BTAP on physical capital and natural capital are stronger than other capitals.

This article calls for more comprehensive experiential evidence about BTAP on poverty alleviation and rural community livelihoods. The present study contributes to the literature in the following three areas. First, it provides direct evidence of the strong association between BTAP and poverty reduction and rural livelihoods in KPK Pakistan, where no evidence or research on BTAP has been established to date. Secondly, this study also contributes to the existing literature using refined empirical analysis. Finally, this research delivers insights into the importance of BTAP.

This study does have one limitation, however. Using household primary survey data, the research is based on data collected from two districts KPK, Pakistan. Other districts located in other regions may have a similar impact, but in a different context. This subject related to BTAP suggests a need for future research, using a cross-border comparative study that may also provide better insight, so scholars can conduct a comparative study. Moreover, these results are based on data collected using a semi-structured questionnaire, affording more information concerning the influence of BTAP on rural livelihoods. Therefore, future studies should conduct longitudinal research. Due to the cross-sectional nature of this study, we could not encompass the characteristics of BTAP, which could be better performed in longitudinal research.

It has been shown that the launch of the BTAP project has positively influenced local community involvement in BTAP, mainly by small-scale forest nursery firms. Based on the findings of the present study, KPK government should arrange seminars with a motive to encourage more household to participate in activities that are BTAP linked, because the wealth index indicates that households connected with BTAP built on existing assets in a more significant way as compared to those who were not involved. This will not only help households to prosper but will also help the government to meet its objective by pushing the project towards success. NGOs such as the UN, Unicef, and WWF may also play their role by distributing the success of KPK to other provinces of Pakistan or maybe worldwide. It is noteworthy that such steps will also assist in tackling the most talked-about issue of global warming. If these efforts can be properly made, it could help the rural households to engage in and improve their livelihoods.

Author Contributions: The following is the description of authors' contribution. First, T.R., C.Y., and N.K. helped in conceptualized the idea of the research design and writing the manuscript. Second, N.K., S.J.S., and M.Z. did statistical analysis. N.K. and T.R. had an equal contribution. S.Y.M. and A.S. provided their intellectual insight and contributed in the collection of data.

Funding: The study presented in this paper is supported by National Social Science Foundation, grantnumber 13BJY032.

Acknowledgments: We would like to acknowledge the financial support from National Social Science Foundation as well as assistance from the School of Economics and Management of Northeast Forestry University, The authors are indebted to Dawood Afridi, the "Evaluation and Monitoring Officer" of BTAP for the field support. We also appreciate for the valuable suggestions and comments made by "Vasily Erokhin" in Herbin Engineering University.

Conflicts of Interest: The authors declare no conflict of interest.

\section{References}

1. Erbaugh, J.T.; Oldekop, J.A. Forest landscape restoration for livelihoods and well-being. Curr. Opin. Environ. Sustain. 2018, 32, 76-83. [CrossRef]

2. Qamer, F.; Shehzad, K.; Abbas, S.; Murthy MS, R.; Xi, C.; Gilani, H.; Bajracharya, B. Mapping deforestation and forest degradation patterns in western Himalaya, Pakistan. Remote Sens. 2016, 8, 385. [CrossRef]

3. Rao, K.; Pant, R. Land use dynamics and landscape change pattern in a typical micro watershed in the mid elevation zone of central Himalaya, India. Agric. Ecosyst. Environ. 2001, 86, 113-124. [CrossRef]

4. Ali, T.; Shahbaz, B.; Suleri, A. Analysis of myths and realities of deforestation in Northwest Pakistan: Implications for forestry extension. Int. J. Agric. Biol. 2006, 8, 107-110.

5. Shi, M.; Qi, J.; Yin, R. Has China's Natural Forest Protection Program Protected Forests?-Heilongjiang's Experience. Forests 2016, 7, 218. [CrossRef] 
6. Ali, A. Forest-based livelihoods, income, and poverty: Empirical evidence from the Himalayan region of rural Pakistan. J. Rural Stud. 2018, 57, 44-54. [CrossRef]

7. Uchida, E.; Xu, J.; Xu, Z.; Rozelle, S. Are the poor benefiting from China's land conservation program? Environ. Dev. Econ. 2007, 12, 593-620. [CrossRef]

8. Qamer, F.M.; Abbas, S.; Saleem, R.; Shehzad, K.; Ali, H.; Gilani, H. Forest cover change assessment in conflict-affected areas of northwest Pakistan: The case of Swat and Shangla districts. J. Mt. Sci. 2012, 9, 297-306. [CrossRef]

9. Angelsen, A.; Kaimowitz, D. Rethinking the causes of deforestation: Lessons from economic models. World Bank Res. Obs. 1999, 14, 73-98. [CrossRef]

10. Agarwal, B. Rural women, poverty and natural resources: Sustenance, sustainability and struggle for change. Econ. Political Wkly. 1989, 24, WS46-WS65.

11. Tiwari, P. Land use changes in Himalaya and their impacts on environment, society and economy: A study of the Lake Region in Kumaon Himalaya, India. Adv. Atmos. Sci. 2008, 25, 1029. [CrossRef]

12. Nguyen, T.V.; Tran, T.Q. Forestland and rural household livelihoods in the North Central Provinces, Vietnam. Land Use Policy 2018, 79, 10-19. [CrossRef]

13. Khan, N.; Shah, S.J.; Rauf, T.; Zada, M.; Yukun, C.; Harbi, J. Socioeconomic Impacts of the Billion Trees Afforestation Program in Khyber Pakhtunkhwa Province (KPK), Pakistan. Forests 2019, 10, 703. [CrossRef]

14. Khan, M.A.; Khan, J.A.; Ali, Z.; Ahmad, I.; Ahmad, M.N. The challenge of climate change and policy response in Pakistan. Environ. Earth Sci. 2016, 75, 412. [CrossRef]

15. Munawar, S.; Khokhar, M.F.; Atif, S. Reducing emissions from deforestation and forest degradation implementation in northern Pakistan. Int. Biodeterior. Biodegrad. 2015, 102, 316-323. [CrossRef]

16. Government of Khyber Pakhtunkhwa. ADP Scheme PC-1 Billion Trees Afforestation Project Phase 3; Government of Khyber Pakhtunkhwa: Khyber, Pakistan, 2017.

17. KPK GOVT, Plant Trees Save Nature, Billion Tree Afforestation Project (BTAP). 2014. Available online: http://billiontreeproject.kp.gov.pk/ (accessed on 20 July 2019).

18. Government of Khyber Pakhtunkhwa. One Billion Trees Afforestation Project. 2014. Available online: https://en.wikipedia.org/wiki/Billion_Tree_Tsunami (accessed on 3 July 2019).

19. WWF. Phase-3, Third Party Monitoring of Billion Trees Tsunami Afforestation Project in Khyber Pakhtunkhwa. Available online: Billiontreeproject.kp.gov.pk/ (accessed on 9 August 2018).

20. Khan, M.A.A. Counting a billion trees. The Express Tribune, 16 January 2016.

21. Pakistan, W. Third Party Monitoring Of The. Billion Trees Afforestation Project. Khyber Pakhtunkhwa, July 2017.

22. Suding, K.; Higgs, E.; Palmer, M.; Callicott, J.B.; Anderson, C.B.; Baker, M.; Gutrich, J.J.; Hondula, K.L.; LaFevor, M.C.; Larson, B.M.N.; et al. Committing to ecological restoration. Science 2015, 348, 638-640. [CrossRef]

23. Sivrikaya, F.; Keleş, S.; Çakir, G. Spatial distribution and temporal change of carbon storage in timber biomass of two different forest management units. Environ. Monit. Assess. 2007, 132, 429-438. [CrossRef]

24. Meyfroidt, P. Approaches and terminology for causal analysis in land systems science. J. Land Use Sci. 2016, 11, 501-522. [CrossRef]

25. Carney, D. Sustainable Livelihoods Approaches: Progress and Possibilities for Change; Department for International Development: London, UK, 2003.

26. Adato, M.; Meinzen-Dick, R.S. Assessing the Impact of Agricultural Research on Poverty and Livelihoods; International Food Policy Research Institute: Washington, DC, USA, 2012.

27. Bond, R.; Kapondamgaga, P.H.; Mwenebanda, B.; Yadav, R.P.; Rizvi, A. Monitoring the livelihood platform: Reflections on the operation of the Livelihood Asset-Status Tracking method from India and Malawi. Impact Assess. Proj. Apprais. 2007, 25, 301-315. [CrossRef]

28. Rakodi, C. A capital assets framework for analysing household livelihood strategies: Implications for policy. Dev. Policy Rev. 1999, 17, 315-342. [CrossRef]

29. Department for International Development. Sustainable Livelihoods Guidance Sheets; DFID: London, UK, 1999; p. 445.

30. Ellis, F. Household strategies and rural livelihood diversification. J. Dev. Stud. 1998, 35, 1-38. [CrossRef]

31. Ellis, F. Rural Livelihoods and Diversity in Developing Countries; Oxford University Press: Oxford, UK, 2000. 
32. Scoones, I. Sustainable rural livelihoods: A framework for analysis. 1998. Available online: https: //opendocs.ids.ac.uk/opendocs/handle/123456789/3390 (accessed on 13 July 2019).

33. Thulstrup, A.W. Livelihood resilience and adaptive capacity: Tracing changes in household access to capital in Central Vietnam. World Dev. 2015, 74, 352-362. [CrossRef]

34. Scoones, I. Livelihoods perspectives and rural development. J. Peasant. Stud. 2009, 36, 171-196. [CrossRef]

35. Carney, D. Sustainable Livelihoods: What contribution Can We Make; Department for International Development: London, UK, 1998.

36. Campbell, B.; Sayer, J.A.; Frost, P.; Vermeulen, S.; Pérez, M.R.; Cunningham, A.; Prabhu, R. Assessing the performance of natural resource systems. Integr. Nat. Resour. Manag. CABI Publ. Oxon UK 2003, 5, 267-292.

37. Erenstein, O.; Hellin, J.; Chandna, P. Poverty mapping based on livelihood assets: A meso-level application in the Indo-Gangetic Plains, India. Appl. Geogr. 2010, 30, 112-125. [CrossRef]

38. Babulo, B.; Muys, B.; Nega, F.; Tollens, E.; Nyssen, J.; Deckers, J.; Mathijs, E. The economic contribution of forest resource use to rural livelihoods in Tigray, Northern Ethiopia. For. Policy Econ. 2009, 11, 109-117. [CrossRef]

39. Chapman, R.; Slaymaker, T.; Young, J. Livelihoods Approaches to Information and Communication in Support of Rural Poverty Elimination and Food Security; Overseas Development Institute: London, UK, 2003.

40. Soriano, D.R.; Castrogiovanni, G.J. The impact of education, experience and inner circle advisors on SME performance: Insights from a study of public development centers. Small Bus. Econ. 2012, 38, 333-349. [CrossRef]

41. Tacoli, C. Understanding the opportunities and constraints for low-income groups in the peri-urban interface: The contribution of livelihood frameworks. 1999. Available online: https://discovery.ucl.ac.uk/169/1/DPU_ PUI_Takodi_opportunities.pdf (accessed on 2 June 2019).

42. Mehta, L. The World Bank and its emerging knowledge empire. Human Organ. 2001, 60, 189-196. [CrossRef]

43. Wiklund, J.; Shepherd, D. Entrepreneurial orientation and small business performance: A configurational approach. J. Bus. Ventur. 2005, 20, 71-91. [CrossRef]

44. Stoian, D.; Donovan, J.; Fisk, J.; Muldoon, M. Value chain development for rural poverty reduction: A reality check and a warning. Enterp. Dev. Microfinance 2012, 23, 54-60. [CrossRef]

45. Ahmed, N.; Allison, E.H.; Muir, J.F. Using the sustainable livelihoods framework to identify constraints and opportunities to the development of freshwater prawn farming in southwest Bangladesh. J. World Aquac. Soc. 2008, 39, 598-611. [CrossRef]

46. Lyon, D.W.; Lumpkin, G.T.; Dess, G.G. Enhancing entrepreneurial orientation research: Operationalizing and measuring a key strategic decision making process. J. Manag. 2000, 26, 1055-1085. [CrossRef]

47. Fafchamps, M. Networks, communities and markets in Sub-Saharan Africa: Implications for firm growth and investment. J. Afr. Econ. 2001, 10 (Suppl. 2), 109-142. [CrossRef]

48. Lyon, F. Micro-enterprises and privatized agricultural services: Information flow, credit and trust in small seed enterprises in Ghana. J. Int. Dev. J. Dev. Stud. Assoc. 1999, 11, 673-685. [CrossRef]

49. Jacobs, B.; Nelson, R.; Kuruppu, N.; Leith, P. An adaptive capacity guide book: Assessing, building and evaluating the capacity of communities to adapt in a changing climate. UTS Scholars. 2015. Available online: https://opus.lib.uts.edu.au/handle/10453/36221 (accessed on 27 July 2019).

50. Krantz, L. The sustainable livelihood approach to poverty reduction. SIDA. Div. Policy Socio-Econ. Anal. 2001, 14, 38-44.

51. Bebbington, A. Capitals and capabilities: A framework for analyzing peasant viability, rural livelihoods and poverty. World Dev. 1999, 27, 2021-2044. [CrossRef]

52. Pakistan, G.O. Census Report. 2017. Available online: http://www.pakinformation.com/population/index. html (accessed on 12 May 2019).

53. Zada, M.; Shah, S.J.; Yukun, C.; Rauf, T.; Khan, N.; Shah, S.A.A. Impact of Small-to-Medium Size Forest Enterprises on Rural Livelihood: Evidence from Khyber-Pakhtunkhwa, Pakistan. Sustainability 2019, 11, 2989. [CrossRef]

54. Ali, A. Economic cost of terrorism: A case study of Pakistan. Strateg. Stud. 2010. Available online: http://pgil.pk/wp-content/uploads/2014/04/Economic-cost-of-terrorism.pdf (accessed on 3 June 2019).

55. PFI, Pakistan Forest Institute. 2012. Available online: http://www.pfi.gov.pk (accessed on 28 August 2019). 
56. Yin, R.; Liu, C.; Zhao, M.; Yao, S.; Liu, H. The implementation and impacts of China's largest payment for ecosystem services program as revealed by longitudinal household data. Land Use Policy 2014, 40, 45-55. [CrossRef]

57. Yin, R.; Liu, H.; Liu, C.; Lu, G. Households' Decisions to Participate in China's Sloping Land Conversion Program and Reallocate Their Labour Times: Is There Endogeneity Bias? Ecol. Econ. 2018, 145, 380-390. [CrossRef]

58. Uchida, E.; Xu, J.; Rozelle, S. Grain for green: Cost-effectiveness and sustainability of China's conservation set-aside program. Land Econ. 2005, 81, 247-264. [CrossRef]

59. Uchida, E.; Rozelle, S.; Xu, J. Conservation payments, liquidity constraints, and off-farm labor: Impact of the Grain-for-Green Program on rural households in China. Am. J. Agric. Econ. 2009, 91, 70-86. [CrossRef]

60. Cameron, A.C.; Trivedi, P.K. Microeconometrics: Methods and Applications; Cambridge University Press: Cambridge, UK, 2005.

61. Mullan, K.; Kontoleon, A.; Swanson, T.; Zhang, S. An evaluation of the impact of the natural forest protection programme on rural household livelihoods. In An Integrated Assessment of China's Ecological Restoration Programs; Springer: Berlin/Heidelberg, Germany, 2009; pp. 175-199.

62. Hogarth, N.J.; Belcher, B.; Campbell, B.; Stacey, N. The role of forest-related income in household economies and rural livelihoods in the border-region of Southern China. World Dev. 2013, 43, 111-123. [CrossRef]

(C) 2019 by the authors. Licensee MDPI, Basel, Switzerland. This article is an open access article distributed under the terms and conditions of the Creative Commons Attribution (CC BY) license (http://creativecommons.org/licenses/by/4.0/). 